Biens Symboliques / Symbolic Goods

Revue de sciences sociales sur les arts, la culture et les idées

2 | 2018

Arpenter la vie littéraire

\title{
The Correspondence of Pierre Bayle, Seventeenth
} Century Philosopher

The Correspondence of Pierre Bayle, Seventeenth-Century Philosopher

La Correspondencia de Pierre Bayle, filosofo del siglo XVII

\section{Éric-Olivier Lochard and Antony McKenna}

Translator. Michelle Arriss, Delaina Haslam and Séverine Sofio

\section{OpenEdition}

\section{Journals}

Electronic version

URL: http://journals.openedition.org/bssg/231

DOI: $10.4000 /$ bssg. 231

ISSN: 2490-9424

Publisher

Presses universitaires de Vincennes

\section{Electronic reference}

Éric-Olivier Lochard and Antony McKenna, "The Correspondence of Pierre Bayle, Seventeenth Century Philosopher", Biens Symboliques / Symbolic Goods [Online], 2 I 2018, Online since 12 April 2018, connection on 04 March 2021. URL: http://journals.openedition.org/bssg/231 ; DOI: https://doi.org/ 10.4000/bssg.231 


\title{
La Correspondance de Pierre Bayle, The Correspondence of Pierre Bayle, philosophe du XvII siècle Seventeenth Century Philosopher
}

\author{
Éric-Olivier Lochard | Antony McKenna \\ traduction | translation \\ Michelle Arriss | Delaina Haslam | Séverine Sofio
}

\section{Comment est né le projet de la base de données?}

La Correspondance de Pierre Bayle est une publication produite à partir de l'ouvrage électronique Le Monde de la correspondance Bayle, pensé et réalisé par notre équipe depuis 1999 à l'aide du logiciel Arcane, conformément au paradigme instrumental "Le monde selon Arcane » (que nous évoquerons de nouveau un peu plus loin). Le projet Arcane a été lancé au début des années 1990 au Centre d'étude du XVIII ${ }^{\mathrm{e}}$ siècle, laboratoire de sciences humaines et sociales du CNRS à Montpellier.

\section{How did the database project begin?}

The Correspondance de Pierre Bayle is a publication produced from the electronic work entitled Le Monde de la correspondance Bayle, devised in 1999 and since developed by our team with the help of the Arcane software program in accordance with the operating instrumental paradigm "Le monde selon Arcane" (addressed more fully below). The Arcane project was launched in the early 1990s at the CNRS Centre of Eighteenth-Century Studies, a Humanities and Social Science laboratory in Montpellier. 


\section{Comment le corpus a-t-il été délimité ?}

Le corpus de la correspondance active et passive de Bayle (Labrousse \&McKenna 1999-2017) ${ }^{1}$ comportequelque 10000 pages manuscrites, éparpillées pour la plupart dans les grandes bibliothèques (Paris, Londres, New York, Leyde). Notre point de départ a été la collecte de plus de 1800 lettres, l'inventaire critique de ces données (établi par Elisabeth Labrousse), la transcription des textes et la traduction des lettres latines et italiennes, et enfin la constitution d'une banque d'images numériques. Ces images accompagnent l'édition annotée du texte des lettres sur le site de la correspondance de Bayle. Les métadonnées de la correspondance sont hors droits et ont été intégrées dans la base EMLO à Oxford. L'édition en ligne comporte actuellement (février 2017) 1099 lettres, et l'ensemble de la correspondance sera disponible gratuitement à tout public en 2022 Il est également intégré dans le corpus des Lumières électroniques (Electronic Enlightenment) de la Fondation Voltaire ainsi que, sous forme XML, dans la base ePistolarium (Université d'Utrecht).

\section{La constitution de la base s'appuie-t-elle sur un ancrage théorique et/ou disciplinaire précis ?}

Le projet Arcane visait à tirer parti des avancées de la recherche en informatique pour les travaux sur l'histoire des idées et de la sociabilité au XVIII ${ }^{\mathrm{e}}$ siècle, matérialisées par des éditions critiques de correspondances et par la réalisation d'un Atlas des correspondances à l'époque moderne.

1 La Correspondance de Pierre Bayle (Oxford, La Fondation Voltaire, 1999-2017, $15 \mathrm{vol}$ ) a été éditée sous la direction d'Elisabeth Labrousse et d'Antony McKenna, avec une équipe composée de Wiep van Bunge, Edward James, Bruno Roche, Fabienne Vial-Bonacci, avec la collaboration d'Éric-Olivier Lochard. Au cours des années, ont également collaboré à cette édition : Laurence Bergon, Hubert Bost, Maria-Cristina Pitassi, Ruth Whelan, ainsi qu'Annie Leroux, Dominique Taurisson et Caroline Verdier.

\section{How was the corpus defined?}

The corpus of the active and passive correspondence of Bayle (Labrousse \& McKenna 1999-2017'1) consists of some 10,000 manuscript pages, housed for the most part among major libraries (Paris, London, New York, Leyde). Our point of departure was the collection of more than 1,800 letters, a critical inventory of this data (set up by Elisabeth Labrousse), the transcription of the texts, the translation of Latin and Italian letters, and finally the creation of a databank of digital images. These images accompany the annotated edition of the letters' content on the Bayle correspondence website. The correspondence's metadata is copyright-exempt and has been integrated into the EMLO database at Oxford. The online edition currently (as of February 2017) consists of 1,099 letters. The entire correspondence will be freely available to the public in 2022. It is also integrated into the corpus of Lumières électroniques (Electronic Enlightenment) of the Voltaire Foundation as well as in XML format in the ePistolarium database (Utrecht University).

\section{Is the design of the database supported by a specific theory and/or discipline?}

The Arcane Project aimed to build on the advances in computer science for the research on the history of ideas and sociability in the eighteenth century; these advances were used to produce critical editions of correspondences, and an Atlas des correspondances à l'époque moderne.

1 With a team consisting of Wiep van Bunge, Edward James, Bruno Roche, Fabienne Vial-Bonacci. With the collaboration of Éric-Olivier Lochard. Over the years, the following people also collaborated on this publication: Laurence Bergon, Hubert Bost, Maria-Cristina Pitassi, Ruth Whelan, as well as Annie Leroux, Dominique Taurisson, and Caroline Verdier. 
Ce travail de recherche s'est articulé autour d'une réflexion épistémologique concernant le processus d'édition savante et plus généralement de création scientifique de connaissances dans les sciences humaines et sociales, dans un nouvel environnement économique et technologique. De nombreuses problématiques ont été abordées dans cette réflexion, en suivant l'impératif de proposer des réponses opératoires.

\section{Quels logiciels avez-vous utilisés pour bâtir l'infrastructure de la base de données, et, le cas échéant, pour leur exploitation statistique?}

Ce travail a donné lieu parallèlement au développement du logiciel Arcane, qui est un instrument d'écriture électronique prototype, destiné à mettre à l'épreuve en conditions réelles les réponses apportées aux problématiques de l'édition critique. II se présente comme les traitements de textes dont les chercheurs ont l'habitude ; le lecteur pourra trouver les caractéristiques de ce logiciel dans trois articles en particulier, le premier écrit en 2001 notamment par l'auteur du logiciel (Lochard \& Taurisson 2001), le second en 2008 (Lochard 2008), et le troisième publié en 2014 par une doctorante (Dufour 2014) qui a utilisé Arcane pour l'édition critique de la correspondance de Marceline Desbordes-Valmore.

Parmi les solutions proposées, certaines rejoignent celles qui sont aujourd'hui couramment admises, même si elles apparaissaient originales à cette époque ${ }^{2}$. D'autres constituent l'originalité de

2 C'est par exemple le cas de l'utilisation d'une base de données, qui fut pourtant mal accueillie à la présentation du logiciel ; c'est aussi le cas du balisage formel de l'information pour garantir sa pérennité, à une époque où le langage SGML (Standard Generalized Markup Language) n'avait pas encore donné naissance à sa version simplifiée, XML (Extensible Markup Language), et où le web était encore confidentiel.
This research is structured around an epistemological reflection concerning the academic editing process and, in a more general sense, the scientific creation of knowledge in the humanities and social science in a new economic and technological environment. Numerous issues were examined in this reflection in line with the requirement to suggest operational solutions.

\section{Which software programs were used to build the database infrastructure and, as the case may be, to treat the data statistically?}

This work resulted at the same time in the development of the Arcane software program, a prototypical electronic writing instrument resembling the word processing that researchers are used to, and designed to test responses to current critical editing challenges. The characteristics of this program can be found in three articles in particular, the first written in 2001 by the author of the program (Lochard \& Taurisson 2001), the second in 2008 (Lochard 2008), and the third in 2014 (Dufour 2014) by a doctoral student who had used Arcane for the critical edition of the correspondence of Marceline Desbordes-Valmore.

Among the solutions proposed, some are commonly accepted today, although they appeared original in nature at the time. ${ }^{2}$ Others

2 Such was the case, for example, for the proposal of using a database, which was poorly received at the launch of the program; it was also the case for the formal markup of information to ensure its perpetuity at a time when the SGML (Standard Generalized Markup Language) had not yet given birth to its simplified version, the XML (Extensible Markup Language), and when the web was still confidential. 
l'instrument Arcane ; nous en détaillons brièvement quelquesunes, en précisant leur mise en œuvre dans la Correspondance de Pierre Bayle.

Un impératif du projet Arcane était d'inscrire l'instrument dans l'environnement " anthropologique " de la création de connaissances en sciences humaines et sociales, en prenant en compte les habitudes des auteurs ${ }^{3}$. Une question épineuse a été de proposer, pour le travail éditorial, une autre image mentale que le livre comme horizon de travail de l'auteur ; cette image devait être à la fois naturelle, opératoire et indépendante de la forme de la publication, ce qui excluait le site web comme solution satisfaisante ; nous avons donc proposé de voir plus abstraitement l'édition savante électronique comme la composition intentionnelle et scientifique, potentiellement infinie, d'un monde

de connaissances multimédia - que le lecteur peut lire et explorer,

- dont on peut extraire des informations pour publication sous diverses formes,

- et qui peut dialoguer avec d'autres mondes pour composer des bibliothèques électroniques.

L'architecture de ces mondes doit être à la fois suffisamment générique pour s'appliquer à un large éventail de projets éditoriaux et suffisamment simple pour faciliter le repérage et l'exploration de l'information par les auteurs et les lecteurs. La solution à cette double contrainte est d'envisager l'ouvrage éditorial comme étant constitué de trois sortes d'objets, dynamiquement liés entre eux, nécessaires et suffisants pour composer la combinatoire sémantique d'un

3 Cet impératif a conduit au choix d'un laboratoire de sciences humaines et sociales pour la production du logiciel, plutôt que d'un laboratoire de sciences et techniques dans lequel le développement aurait peut-être pu se faire de manière plus « confortable ». constitute the originality of the Arcane instrument. We detail some of them briefly by specifying their application in the Correspondance de Pierre Bayle.

One requirement of the Arcane project was to situate the instrument in the "anthropological" environment of the production of knowledge in the humanities and social science by taking into account the habits of authors. ${ }^{3}$ One thorny issue was that of suggesting, for the editing work, another mental image than that of the book as the author's horizon of work. This image had to be natural, functional, and independent of the form of the publication: a website was thus excluded as a satisfactory solution. Hence, we proposed considering electronic scholarly editing more abstractly as the intentional and scientific, potentially infinite, composition of a world of multimedia knowledge

- that the reader can read and explore

- from which one can extract information for publication in various forms

- and which can dialogue with other worlds in order to compile electronic libraries.

The architecture of these worlds must be at the same time generic enough to apply to a wide range of editing projects, and simple enough to make it easy for authors and readers to locate and explore the information. A solution to this dual constraint is to consider the editorial work as comprised of three types of object, dynamically interconnected, both necessary and sufficient to compose the

3 This requirement led to the choice of a laboratory in humanities and social science for the production of the software instead of a laboratory specialized in science and technique in which its development would have been more "at home." 
monde de connaissances multimédia, et qui peuvent fonctionner comme des portes d'entrée dans l'ouvrage électronique : - des sujets d'intérêt intentionnel du projet éditorial (" de quoi il parle »), qui, regroupés en types (dans la base Bayle : personnes, lieux, livres, lettres...), composent la matérialité du monde, ses habitants, par généralisation des index cumulatifs ; - des documents-enrichis (" qu'est-ce qu'on en dit »), flots informationnels multimédias pour décrire, illustrer, annoter, interpréter le monde (dans la base Bayle : lettres, qui figurent donc comme sujets et comme documents-enrichis, notes, appendices, manuscrits, etc.)

- des relations («qu'est ce qu'on en sait») pour organiser les sujets, décrire des relations factuelles ou repérer formellement des informations prédicatives (dans la base Bayle : relations entre les correspondants et les personnes mentionnées dans les lettres).

Dans le monde de la Correspondance de Pierre Bayle, il y a essentiellement cinq types de sujets : 2200 lettres-sujet qui décrivent les lettres (leur contenu est un document) et composent l'inventaire, 11000 personnes (expéditeurs, destinataires, personnes citées dans les lettres), 2700 ouvrages critiques modernes, 150 lieux géographiques, et 75 personnages (littéraires et théâtraux). Chaque sujet possède une fiche de métadonnées composée selon son type : la fiche des lettres-sujet, par exemple, se compose notamment de l'auteur, du destinataire, des lieux d'envoi et de destination, et de la date d'envoi.

Un document-Arcane est un couple formé d'un support multimédia (suite de signes pour un texte, de pixels pour une image, d'unités de temps pour les sons et vidéos) et de l'ensemble de ses enrichissements, valeurs objectives ou subjectives que l'auteur attache explicitement et intentionnellement à une séquence du support pour le qualifier, le représenter, le structurer, l'indexer, semantic combination of a world of multimedia knowledge, and which can function as portals into the electronic publication: - subjects of intentional interest of the editorial project ("what he is talking about"), categorized according to type (in the Bayle database: people, places, books, letters), and which make up the materiality of the world and its inhabitants, by generalizing the cumulative indices - enhanced documents ("what has been said about them") multimedia information streams to describe, illustrate, annotate, and interpret the world (in the Bayle database: letters that thus serve as subjects and as enhanced documents, notes, appendices, manuscripts, etc.)

- relationships ("what is known about them") in order to organize the subjects, describe the factual relationships or formally locate predicative information (in the Bayle database: relationships among correspondents and the individuals mentioned in letters).

Within the world of the Correspondance de Pierre Bayle, there are essentially five types of subject: the inventory consists of 2,200 subject-letters which describe the letters (their content is a document); 11,000 individuals (senders, addressees, people cited in the letters); 2,700 modern critical publications, 150 geographical locations and 75 (literary and theatrical) characters. Each subject possesses a metadata form composed according to its type: the subject-letters form, for example, consists in particular of the author, the addressee, the places the letter was sent from and to, as well as the date it was sent.

An Arcane-document is a link comprised of a multimedia support (sequence of signs for a text, of pixels for an image, of units of time for sounds and videos), and of the combination of its enhancements - objective or subjective values that the author explicitly and intentionally attaches to a sequence of the medium in order to qualify, represent, structure, index, or annotate it, etc. In the world 
l'annoter, etc. Dans le monde de la Correspondance de Pierre Bayle, les manuscrits (1 793) et les textes établis (2 040) sont des documents-Arcane liés à la lettre-sujet correspondante, ce qui permet de passer très facilement de l'un à l'autre.

Un enrichissementest une information logique attachée au support du document par une ancre (séquence dans un texte, partie rectangulaire d'une image, séquence dans un son ou une vidéo) à l'aide d'un enrichisseur ; les enrichissements (titre, italiques, emphase, langue étrangère...) sont librement crées et prescrits par l'éditeur en fonction du projet éditorial, en fixant diverses opérations automatiques comme la mise en forme typographique des ancres, ou encore le formatage à effectuer lors d'une exportation de document - par exemple, par un balisage TeX ou XML. Dans Arcane les enrichissements sont enregistrés séparément des supports ; cette particularité a plusieurs avantages, notamment de permettre aux enrichissements d'être des portes d'entrée dans le monde, ou encore de permettre à l'auteur de proposer diverses vues d'un document en faisant opérer sur le support une partie seulement de ses enrichissements.

La Correspondance compte deux sortes d'annotations, enrichissements qui attachent l'annotation (un document-Arcane) à une ancre : l'annotation explicative (22 500 notes distinctes portant sur l'identification des personnes, des événements et des questions traitées dans les lettres) et l'annotation critique (13 000 notes distinctes portant sur l'état du manuscrit : ratures, taches d'encre, encre pâlie, texte illisible...).

L'indexation, simple ou relationnelle, est un enrichissement qui attache un sujet (ouvrage ou personne) à l'ancre ; les 70000 indexations présentes dans la Correspondance ont permis de composer automatiquement les index et bibliographies cumulatifs par volume et généraux pour l'ensemble des volumes l'indexation permet également d'accéder à partir de sa fiche à toutes les occurrences d'un sujet dans les documents. of the Correspondance de Pierre Bayle, manuscripts $(1,793)$ and established texts $(2,040)$ are Arcane documents associated with the corresponding subject-letter, thus facilitating movement from one to the other.

An enhancement is a logical piece of information attached to the document medium by an anchor (a sequence, a rectangular part of an image, a sequence in a sound or a video) with the help of an enhancer, the enhancements (title, italics, emphasis, foreign language, etc.) are freely created and stipulated by the editor according to the editing project, by setting various automatic operations such as fixing the anchors' typographical form, or choosing the format to use when exporting the document - for example, using a TeX or XML markup. In Arcane, enhancements are recorded separately from the media; this unique characteristic has several advantages. In particular, it enables enhancements to be ports of entry into the world, and allows the author to suggest different views of a document by making only part of its enhancements operate on the medium.

The Correspondance features two types of annotation, enhancements which link the annotation (an Arcane document) to an anchor: the explicative annotation (22,500 separate notations regarding the identification of the people, events, questions, addressed in the letters) and the critical annotation (13,000 separate notations about the condition of the manuscript: crossings-out, ink stains, faded ink, illegible text, etc).

The indexation, whether simple or relational, is an enhancement which attaches a subject (publication or individual) to the anchor: the 70,000 anchors of the Correspondance have enabled the automatic compilation of cumulative indexes and bibliographies for each volume, and general indexes for the collection of volumes as a whole. The indexing also allows access via its form to all occurrences of a subject in the documents. 
Les enrichissements « Glossaire » (2 000) attachent un terme du dictionnaire du monde à l'ancre.

Les autres enrichissements (185 000 au total) consistent à poser des étiquettes sur l'ancre pour la qualifier : titre, langue étrangère, vers, citation, liste, etc., ou à créer des liens vers diverses cibles.

Les relations sont des combinaisons formelles qui servent à établir des liens sémantiques et dynamiques entre les objets du monde, en particulier entre les sujets, ou à interpréter formellement le contenu d'une ancre d'un document. Elles sont produites par application d'un relater (lien hypertextuel) ; ceux-ci sont librement créés et prescrits par l'éditeur en fonction du projet éditorial, en déterminant la liste des arguments de la combinaison, ainsi que leur type : on peut, par exemple, introduire entre tous les sujets de la base des relations de tous les types (arborescence, inclusion, parenté, dépendance, domination, protection, amitié ou plus, etc.).

La Correspondance de Bayle utilise deux relateurs ${ }^{4}$ : ProduitPar (2 650 occurrences) qui relie un auteur de type sujet-personne et un ouvrage de type sujet-ouvrage, et EtreEnRelation (150 occurrences) qui relie la personne à l'origine de la relation avec une autre (dont le nom est mentionné dans telle lettre) ; ces 150 relations (que nous avons établies à titre expérimental sur une période donnée pour explorer leur pertinence) sont ancrées dans les lettres par un enrichissement ad hoc.

Les documents dynamiques sont définis par un script composé par l'utilisateur et appliqué sur des éléments du monde. Ils sont

4 D'autres ouvrages, portant sur la sociabilité par exemple, en comporten plusieurs dizaines, pour distinguer de manière nuancée les différents types de relations entre les personnes.
The "Glossary" enhancements $(2,000)$ link a term from the dictionary of the world to the anchor.

The other enhancements (185,000 in total) consist of adding labels to the anchor in order to describe it: title, foreign language, verse, citation, list, etc., or to create links with various targets.

Relationships are formal combinations that serve to establish semantic and dynamic connections between objects in the world, in particular among subjects, or to formally interpret the content of a document's anchor. They are produced by the application of a relator (hyperlink). These are freely created and prescribed by the editor according to the editing project, thus determining the list of the combination arguments as well as their type: one could, for example, introduce relationships of all types among all the basic subjects (arborescence, inclusion, family, dependence, domination, protection, friendship, or more, etc.).

The Correspondance de Bayle uses two relators ${ }^{4}$ : ProduitPar (ProducedBy - 2,650 occurrences) which links an author of the type subject-person, and a work of the type subject-work; and EtreEnRelation (BeRelated -150 occurrences) which links the person who initiated the relationship with another (whose name is mentioned in the letter). These 150 relationships (which we have established for experimental purposes for a given period in order to investigate their pertinence) are anchored in the letters by an ad-hoc enhancement.

Dynamic documents are defined by a script composed by the user and applied to elements of the world. They are effectively calculated

4 Other works, those dealing with sociability, for example, consist of dozens of them in order to distinguish the different types of relationships among individuals in a more nuanced manner. 
effectivement calculés et produits en réponse à une instruction de l'utilisateur, par exemple le document composé des ancres d'une indexation par un sujet donné ou des ancres d'un enrichissement comme "Passage à revoir ", ou encore la représentation cartographique de lettres-sujet sur une carte d'Europe, en utilisant les coordonnées des sujets-lieux géographiques figurant comme lieu d'expédition et de destination dans la fiche des lettres-sujets.

Les publications, comme les échanges avec d'autres systèmes d'information, sont produits par exportation automatique d'un document, conduite par un script précisant les objets à exporter et une feuille de style indiquant l'opération à effectuer sur les ancres des enrichissements, le balisage par exemple.

\section{Pourriez-vous donner en exemple un ou deux résultats scientifiques (attendu ou surprenant) obtenus à l'aide de la base de données ?}

Ces relations permettent d'établir, par exemple, la pertinence des lettres perdues et des contacts indirects avec des personnes mentionnées dans les lettres connues. Si on se fie à la seule représentation du réseau des lettres connues, on peut se tromper lourdement sur l'univers du sujet principal (en l'occurrence, Pierre Bayle), car ses correspondants paraissent n'avoir aucune relation entre eux. En faisant apparaître les lettres perdues, la correspondance est beaucoup plus complète. Si on y ajoute ensuite l'ensemble des relations (établies par les relateurs), on entre bien mieux dans la représentation que pouvait se faire Bayle, de ce monde de correspondances et de relations plus ou moins directes et on saisit mieux la nature objective de ces réseaux. and produced in response to an instruction by the user; for example, the document composed of the anchors of an index by a given subject or the anchors of an enhancement such as "passage to be re-examined," or even the cartographical representation of subjectletters on a map of Europe using coordinates of the geographical subject-places acting as place of expediting and of destination in the subject-letters file.

Publications, such as exchanges with other information systems, are produced by automatic exportation of a document, led by a script specifying the objects to be exported and a style sheet indicating the operation to be carried out on the enhancement anchors - for example, on markup.

\section{Could you offer one or two examples of scientific (whether consensual or surprising) results obtained with the help of the database?}

These relationships enable the establishment, for example, of the pertinence of lost letters and indirect contacts with the people mentioned in the known letters. If we were to rely only on the representation of the network designed by the known letters, we could be seriously mistaken about the world of the principal subject (in this case, Pierre Bayle) because his correspondents appear to have no relationship to one another. By revealing letters that have been lost, the correspondence is far more complete. If we add to that the total number of the relationships (established by relators), we have a much better insight into Bayle's own representation of this world of correspondence and of more or less direct relationships; we can then better understand the objective nature of these networks. 
Autre exemple : les relations permettent de représenter les réseaux de relations directes et indirectes de façon hiérarchique, de sorte qu'on comprend mieux la situation et les intentions de Bayle. Ainsi, pour les besoins de la rédaction de son Dictionnaire, il a recours à un petit nombre d'amis qui font office de "secrétaires de la République des Lettres ". Ceux-ci relaient ses questions (bibliographiques, historiques, etc.) aux spécialistes dans différents domaines (bibliographie, histoire, numismatique, généalogie, etc.) : on voit alors que Bayle reçoit directement ou indirectement les informations de son Dictionnaire de la part d'une foule de sujets qui, dans leur ensemble, constitue sa représentation de la République des lettres et la structure objective de cette communauté

Les documents PDF des quinze volumes de l'édition papier ont été produits par exportation des lettres-documents au format LaTeX, puis composés par ce logiciel à l'aide d'un fichier de style interprétant les directives de mise en page de la Fondation Voltaire,

l'éditeur commercial.

L'édition web de la Correspondance, servie par une version du système de publication libre SPIP élaborée par Pierre Mounier et désormais maintenue par Cindy Tessier (DSI, Université JeanMonnet de Saint-Etienne), est alimentée par l'exportation d'un document $X M L$ réimporté dans le serveur.

L'intégration de l'inventaire de la Correspondance dans la base EMLO à Oxford a été faite par exportation des métadonnées des lettres-sujet, et celle de la Correspondance complète dans base ePistolarium (Université d'Utrecht) par exportation des lettresdocument dans un format TEI.

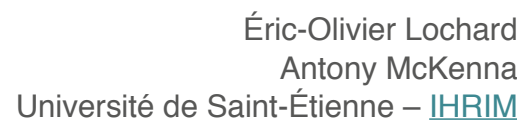

In another example: relationships enable the hierarchical representation of direct and indirect networks in such a way that we have a better understanding of Bayle's situation and intentions. For the purpose of compiling his Dictionnaire, he was able to call upon a small number of friends who acted as "Secretaries of the Republic of Letters." They would pass his questions (bibliographical, historical, etc.) on to specialists of various fields (bibliography, history, numismatics, genealogy, etc.). In this way, we see that Bayle received, directly or indirectly, the information for his Dictionnaire from a great number of subjects who, considered together, make up his representation of the Republic of Letters and the objective structure of this community.

PDF versions of the fifteen volumes of the paper edition were produced by exporting the document-letters to LaTeX format, then composed with the help of a style sheet interpreting the page layout instructions of the commercial editor, the Voltaire Foundation.

The web edition of the Correspondance is served by a version of the free publishing system SPIP developed by Pierre Mounier and, from then on by Cindy Tessier (DSI, Université Jean-Monnet de Saint-Etienne), and is supplied by the exportation of an XML document re-imported into the server.

The integration of the Correspondance inventory into the EMLO database at Oxford was done through the exportation of the subjectletters metadata, and that of the complete Correspondance into the ePistolarium database (Utrecht University) through the exportation of the document-letters in TEI format.

Éric-Olivier Lochard

Antony McKenna

Université de Saint-Étienne - $\underline{\text { IHRIM }}$ 


\section{Références bibliographiques}

LABROUSSE Elisabeth \& MCKENNA Anthony (dir.) (1999-2017). Correspondance de Pierre Bayle. Oxford, La Fondation Voltaire, 15 vol.

LOCHARD Éric-Olivier \& TAURISSON Dominique (2001). " "Le monde selon Arcane" : un paradigme instrumental pour l'édition électronique ». Cahiers GUTenberg, 39-40 : 89-105. [En ligne] http://manuscritdepot.com/edition/ documents-pdf/paradigme-ed-electronique.pdf [consulté le 15 janvier 2018].

LOCHARD Éric-Olivier (2008). " L'édition de manuscrits au prisme du paradigme instrumental Arcane ». Recherches \& Travaux, 72 : 83-95. [En ligne] https://recherchestravaux.revues.org/92 [consulté le 15 janvier 2018].

DuFour Delphine (2014). « L'enjeu numérique dans l'édition de la correspondance de Marceline Desbordes-Valmore ». PhiN-Beiheft, 7 64-75. [En ligne] http://web.fu-berlin.de/phin/beiheft7/b7t04.pdf [consulté le 15 janvier 2018].

\section{References}

LABROUSSE Elisabeth \& McKenNA Anthony (eds.) (1999-2017) Correspondance de Pierre Bayle. Oxford, La Fondation Voltaire, 15 vol.

LOCHARD Éric-Olivier \& TAURISSON Dominique (2001). "Le monde selon Arcane': un paradigme instrumental pour l'édition électronique." Cahiers GUTenberg, 39-40: 89-105. [On line] http://manuscritdepot.com/ edition/documents-pdf/paradigme-ed-electronique.pdf [accessed 15 january 2018].

LOCHARD Éric-Olivier (2008). "L'édition de manuscrits au prisme du paradigme instrumental Arcane." Recherches \& Travaux, 72: 83-95. [On line] https://recherchestravaux.revues.org/92 [accessed on 15 january 2018].

DuFour Delphine (2014). "L'enjeu numérique dans l'édition de la correspondance de Marceline Desbordes-Valmore." PhiN-Beiheft, 7: 64 75. [On line] http://web.fu-berlin.de/phin/beiheft7/b7t04.pdf [accessed on 15 january 2018]. 